\title{
ABOUT THE NEW CZECH LEGAL REGULATION OF THE CONTRACT FOR WORK
}

\section{O NOVÉ ČESKÉ PRÁVNÍ ÚPRAVĚ SMLOUVY O DÍLO}

\author{
Karel Marek \\ Vysoká škola finanční a správní \\ https://doi.org/10.33542/SIC2019-2-06
}

\begin{abstract}
A contract for work is probably the second most widely used type of contract (next to the purchase contract). Therefore its complex legal regulation is very important for the unambiguous definition of the rights and obligations of the parties to the contract. By the contract for work, the contractor undertakes to perform certain work and the employer undertakes to pay the price for its performance. Work as defined by the law manufactures specified products (provided the manufacture does not fall under the notion of a purchase contract), the maintenance, repair or modification of certain items or the result of other activities. Fabrication, repair or modification of buildings or parts thereof shall be always covered by contracts for work.
\end{abstract}

\begin{abstract}
ABSTRAKT
Smlouva o dílo je žrejmě druhým nejčastěji použivaným smluvním typem. Její právní úprava je proto velmi důležitá pro jednoznačné vymezení práv a povinností smluvních stran. Smlouvou se zhotovitel zavazuje zhotovit dílo a objednatel se zavazuje zaplatit cenu za jeho provedení. Pojem díla je definován zákonem. O dílo se jedná (za predpokladu, že dodávka nespadá pod kupní smlouvu) pokud se jedná o činnosti, údržbu, opravy nebo úpravy. Při zhotovování staveb nebo jejich částí, jejich opravy a údržbu se jedná o dilo vždy.
\end{abstract}

\section{INTRODUCTION}

The new legislation, given by the Czech Civil Code, Law No. 89/ 2012 Coll and effective from 1 January 2014, replaced the regulation of the contract for work, as contained in the abolished Civil Code of 1964 , as well as the in the Czech Commercial Code of 1991 that was also cancelled by the new Civil Code of 2012.

The paper analyses and assesses the most important provisions of the new shape of the contract for work. The article is based on our current work. The basis for the draft new legislation was taken from the former regulation of this contract by the Commercial Code and having taken regard to certain legal regulations by other countries, because the concept of contract work as contained in the former Civil Code was strongly influenced by its original design from 1964 and the by patterns of the Civil Code of 1950. In some respects certain provisions of the former Code of International Trade were also taken into account, the normative structure of which was "borrowed" by the later Commercial Code. The new Civil Code regulation, however, should be more precise and clearer than the previous arrangements. 
In the interest of clarity, the draft legislation is structured so that the introductory rules cover contracts for work in general and thereafter follow rules for deviation from the price of the work according to the agreed budget, for the work carried out on real estate and works concerning intangible assets.

In view of the fourth industrial revolution, with the development of automation and the anticipated extensive technology deliveries, the subject is extremely topical.

A contract for work is probably the second most widely used type of contract (next to the sales contract ), therefore we see it as useful to present more details on its new regulation as brought by the New Civil Code (hereinafter "CivC").

The fundamental provisions specify that by the contract for work the Contractor undertakes to perform at his/her cost and risk the work for the customer and the customer undertakes to take over the work and pay the price.

The price of the work is agreed sufficiently clearly, if, at least, the method of its determining is settled or if, at least, the price set by an estimate is specified. If the parties are willing to enter into a contract without specifying the price, then the price for the same or at least for a comparable work at the time of the conclusion of the contract and under similar terms and conditions shall be accepted.

The Explanatory Memorandum to the CivC states that the new legislation should remove the dualism of civil and commercial regulations of contract for work. The valid rules contained in the former Commercial Code ("ComC" hereinafter) have been taken as the basis of the proposal of the new legal regulation with due regard to some regulations abroad because the concept of a contract for work in the current CivC is tributary to its original concept from 1964 and the model of the Civil Code of 1950. In certain aspects it takes regard to some provisions from the former Code on International Trade, whose normative constructions were taken over by the valid ComC but which have often been formulated more precisely and clearer than the current rules.

In order to be sufficiently clear, the draft regulation was structured so that it first specifies the contract in general, and then deviations concerning the price of the work are agreed under a budget, on the work carried out on real estate and work with intangible results.

The work is conceived as a standard activity (work), whereas the work as implementation of the contract for work differs from the work provided by the employee on the basis of a contract of employment in particular that, according to a contract for work, the contractor carries out activities independently, according to its own schedule, with its own resources and at its own risk, and does not underlie any constant supervision or control by the customer.

As a principle, the contractor performs the work in person or arranges for the performance under his personal supervision only if this is necessary due to his personal capacity or to the nature of the work. If this is not the case, the contractor may assign the work to be performed or to be supervised by another person, in which case he is responsible according to the general law of contracts, for the proper performance of the work as it would be performed by him alone.

In order to perform the work it is very often necessary that the customer must provide assistance in various forms (deliver a machine to perform repairs, allow entry to the building/ real property, to arrange the construction site, etc.). The CivC rules, on a General level, for various aspects of these situations. The Contractor serves not as the person dispensing orders of the customer, therefore he does not principally obey his instructions. However, such a relationship may be agreed upon to some extent. In the same way it may (and sometimes has to) be agreed that the customer delivers to the Contractor things or material for the performance of the work, etc. In these cases the regulation is set that the Contractor, as the 
person who performs the work on its own responsibility, must examine with sufficient care for all orders given by the customer as well as, where appropriate, all things delivered by the customer to perform the work and draw his attention to their eventual defects. In the CivC are also rules for situations where the customer, although being contractually obliged, shall not deliver the thing.

Just because it is the rule that the contractor does not obey the orders of the customer in carrying out the work the CivC must rule for the right of the Customer to control the performance of the works. Even in that direction the CivC has incorporated the existing concept of the Civil Code 1964 and the ComC.

The obligation to perform the work shall be met by the Contractor upon its completion and passing, the Customer will meet his duties by the payment of the price. The CivC also rules for special cases in which the work is to be passed in parts, when the price is specified only by an estimate, when the work is aborted for various reasons, etc. As regards the defects in the work, the CivC makes reference, in accordance with the previous arrangements, to the appropriate application of the provisions concerning the Sales contract.

\section{MATERIAL AND METHODS}

The goal of the contribution is to evaluate the new legal regulation In doing this we shall make use preferentially of the comparative and analytic methods.

According to the Explanatory Memorandum the work is conceived as an activity (of work), whereas the work as implementation of the contract for work differs from the work provided by the employee on the basis of a contract of employment in particular that the Contractor does not underlie any constant supervision or control by the Customer. We may note that there are a couple of cases, and especially in the construction service, where we have a commercial relationship established and there is a technical supervision carried out continuously.

As we can see from the legislation, the work is an activity, but compared to the previous CivC, however, it may be materially captured. Because the new CivC is based on the previous ComC, it may be more acceptable for the business than for the non-business sphere.

The CivC thereafter rules for situations where the Contractor may entrust the performance of work to another person (persons). However, he remains responsible for it as if carried out by him alone.

The contract for work is often used especially in construction, where it is necessary to handle the terminology settled and where the use of the suitable term with its content given as usage in trade (business) may be the starting point for the determination of the obligations of the Contracting Parties. Therefore, we first pay attention to these issues.

Under building construction work we understand a work irrespective of its constructiontechnical design, purpose and duration. In addition to the simple or line constructions, especially for the constructions in industries, the construction is, as a rule, divided into: construction part of the building (which, however, also includes other than construction works, and those that attributed to the construction part, e.g. light wiring, medical equipment, central heating systems, etc.) and technological part of the building (also called the machinery and technological parts of buildings).

The construction part of the building is structured into construction objects. A construction object is defined as a spatially coherent part of the building, which forms its basic part.

The operating unit (OU) is a complex of mutually functionally connected operational settings, completing the entire technological process and/or the special technological process 
of one-way use, as specified by the construction documentation and, as a rule, put into operation in a continuous time. The operating unit is its main features characterized by the type of the process for which is established.

The operating unit splits into operational settings, as a rule into several operating settings of machinery, electrical or other equipment (in the case of technological structures) for the basic technological process (or for a special technological process), and into other operational settings for additional technological processes. For an operational unit shall be held complete technological equipment e.g. for an engineering plant or sewage treatment plant.

In the case of complex production structures, it is possible to divide the operating unit into partial operating units. The operation unit of these constructions is characterized by the complexity of technology from the entry of raw materials, semi-finished products and other materials intended for processing up to the outlet of final products, including, if necessary, packaging and shipping.

The partial operating unit (POU) is a complex of mutually functionally related operational settings, performing partial parts of a complex technological process and/or minor parts of a complex special technological process as specified by the construction documentation and, as a rule, put into operation in a continuous time.

The POU as well is divided into operational settings, in case of constructions for manufacturing characterized by a closed technological process that is on the input and output usually terminated by partial cut-offs (intermediate in-process store, landfill, etc.). When designing the division it is necessary to ensure that the complexity of the relevant component of the operational complex is secured so as to ensure the implementation of independent complete tests of POUs and their gradual passing and preparation for subsequent field tests (warranty tests).

Operational setting (OS) is a functionally integrated part of the operating unit, a POU or technological part of the construction (machinery and equipment forming a separate functional unit), consisting of a complex of the technological equipment, performing a partial technological (i.e. separate) process and/or a technological special process, or a complex additional technological process. These are specified by the construction documentation and, as a rule, put into operation in continuous time.

Operational setting is, as a rule, divided into operating units or into operational units and basic units or directly into base units. If appropriate (e.g. for the construction performed by sub-contractors), an operating setting is divided into partial operational settings or operational settings and operational units or directly into basic units.

Partial operating setting (POS) is a functionally comprehensive part of the operational setting, consisting of a complex of technological equipment and performing a separate partial technological process (or a special or a supplementary technological process), designated by the construction documentation and put into operation in continuous time. It is used only exceptionally, for very complicated and complex equipment, when it is useful or necessary to put between the operating setting and the operating unit interstage. It shall be divided into operating units, or operational units and basic units or directly into basic units.

The operating unit (OU) is functionally a comprehensive part of an operating setting or of a POS, consisting of a complex of technological equipment and carrying out a comprehensive part of the technological process specified in the construction documentation.

The OU may be divided into basic units. The functional structure of the operational unit shall be specified in the construction documentation and its function can be verified only by a cumulative test of all basic units forming the OU.

The basic unit (BU) is a product supplied by one manufacturer that has a separate 
destination as a unit, fulfils a specified principal or complementary function with permanent operation and consists of a structurally enclosed unit that cannot be completely divided into two or more functional units. In the construction documentation the BU shall not be subdivided any more. The term basic unit refers in principle to a single-part delivery, the designation separate machine or equipment

\section{RESULTS AND DISCUSSION}

The fundamental provisions specify that the Contractor undertakes to perform at his cost and risk a work for the customer and the customer undertakes to take over the work and pay the price.

So, as opposed to the wording of the fundamental provisions of the ComC, the text is amended by the performance for the risk and expense of the Contractor, which was the consequent wording contained in the ComC in its Section 537, a follow-up to the fundamental provisions. The text of the fundamental provision was also amended by the inclusion of the obligation to take over the work that was also in the Section 537ComC.

The price is ruled differently by the fundamental provisions. The CivC specifies that the price shall be deemed or agreed upon with enough determinacy, if, at least, the method of its determining is agreed, or if it is determined at least by an estimate. If the parties are determined to enter into a contract without specifying a price, it shall be deemed for an agreed price a price paid for the same or comparable work at the time of conclusion of the contract and under similar terms and conditions. We remind that the conclusion of the contract by the will of the parties not to specify the price of the work can't be recommended especially in the case of large, atypical of industrial constructions.

The specification of the work in the ComC has been defined by the fundamental provisions in Section 536, in relation to the fundamental provisions of the sales contract and the provisions in Sections 409 to 410.

In the CivC the Section 2587 is devoted to this issue and it specifies that the work means manufacturing of a certain thing should it not fall under the sales contract and, further on, the maintenance, repair or modification of a thing, or an activity with a different outcome. The work is always the manufacture, maintenance or modification of a construction or parts thereof.

When concluding the Treaty, mainly the Contractors (similarly as the Buyer in the case of a sales contract) should, in our view, consider the inclusion of an article "Meaning and purpose of the Treaty" (we recommend its inclusion). The content of this article is not just a proclamation but may be linked to serious legal consequences in connection with other provisions of the legal regulation.

We should also not miss in the contract for work in construction basic information about the construction. We hold it appropriate to include the statement of the Customer (the Constructor), that the construction is properly licensed (potential fines or termination of illegal construction do not affect only the Customer, but brings a lot of problems to the Contractor as well). It is appropriate to agree when the Customer shall forward (or communicate its release) the license - building permit to the Contractor (if it was not released before the conclusion of the contract). It should be passed no later than upon delivery and taking over of the construction site. We may especially recommend in the Treaty to place the name and location of the construction and its characteristics (e.g., that it is construction of a permanent, temporary character etc.). If the data on the purpose and value of the construction should not be explanatory enough, the contract may also include an article about the importance of the building. 
We may recommend, in addition to the accurate identification of the contracting parties in contracts for construction, to include also:

- the other participants in the construction

- details of the investor (or information about future user)

- at least a basic solution of the supply system (i.e., persons supplying to the investor, the manner of supply) and specification of contracted performance, including the determination of the functions of General Designer, general supplier (Contractor), technological parts of construction and general supplier of construction of part of the building

- In addition to the precise specification of parties to the contract, i.e. the Contractor and the Customer, it can be added - and it's also very practical - who are their statutory bodies and individuals (officers, employees) authorized to negotiate upon possible contractual amendments

- In order to facilitate the fulfillment of obligations arising from the tax legislation (in particular from the law on value added tax) the Tax ID

- If, before starting the manufacture - goods to be used for the manufacturing shall be sent, specification of warehouse should not be missed in the contract, as well as the transporting disposition, i.e. address of the recipient, the agreed mode of transport and the place of destination (it is possible also to agree for packaging). The equipment supplied in the packaging should be signed appropriately (refer to the agreed code), to make it clear for which unit or operational setting it is specified

- It is also appropriate to agree upon a person who will act as the Building Inspector of the Contractor and who will perform the functions of Technical Supervisor of the investor, therefore, to include provisions about who shall be entitled on the construction site to records and confirmations to the Construction (Assembly) Journal and to control the work done.

- For more complex constructions, the contract may list also other persons, etc. representatives for the technical issues (to resolve technical problems, or submit technical documentation for drafts of amendments to contracts resulting from the proposed technical changes), the Coordinator (responsible for coordinating the work of subcontractors and/or other suppliers delivering directly to the investor), the person responsible for work safety at the construction site, etc. These officials, however, are not generally entitled to negotiate changes in contracts (technical representatives can, however, be authorized to agree to such minor changes to the project and in the project is consistently indicated; e.g., there may be a change in the data dimension setting the distance of individual machines from each other). For larger buildings it may also be agreed who on behalf of the Contracting Parties shall be entitled to perform the submission and acceptance of the works. Who is called the contractor and the principal responsible geodetic surveyor

- For larger buildings it may also be agreed who shall be entitled on behalf of the Contracting Parties to perform the passing and taking over of the work and/or who is the so called responsible geodetic surveyor of the Contractor and Customer.

- As a rule, in the contracts will be specified the person performing the so-called personal supervisor of the designer (not necessary for a subcontract on the lower level of the supply chain).

The provisions of Section 2588/1 CivC rule for cases where nobody else than the specified Contractor can perform the work, as the performance of the work is dependent on its specific know-how. This may be e.g. in the case of an artistic blacksmith who has committed himself to create a specific original work. In this case the obligation shall expire by a loss of his 
capability (e.g. by an accident or illness) or by his death. However, this does not apply if the work may be performed by a person who took over the business of the Contractor as his successor.

In accordance with Section 2588/2 CivC the death of the Customer shall not terminate the obligation by itself, unless the execution of the obligation becomes by this fact impossible or unnecessary. It is also true in the case of the obligation's extinction by the Customer's death.

The work need not be conditioned by the personal characteristics of the Contractor- or it is not required due to the nature of the work (e.g., for maintenance of beverage vending machines). In such cases the contractor shall not be obliged to perform the work personally and may have to arrange for it through a Subcontractor. However, beside the latter cases it is deemed to be agreed that the Contractor shall perform the work in person or under his personal supervision.

If not otherwise agreed, the Contractor shall procure all that is necessary for the work performance. If no time for performance of the contract is agreed, it shall be performed within an appropriate time limit. Time of performance of the contract work shall be established in favor of the Contractor.

Sometimes there will be not only one time of the contract performance time as the total duration, but often there will be contracted the time for a partial performance and time for consideration of the other party shall be agreed upon. Contracts should specify these questions in a concrete manner.

According to the agreed extent of performance it can be agreed in case of supplies for a construction whose documentation shall be handed over by the Customer to the Contractor, if the contractor will prepare the construction design (if this is agreed, the contractor may also arrange for the building permit). However, it can also be agreed that the relevant construction design and building permit shall be arranged for by the Customer and passed to the Contractor.

However, if the particular degrees (types) of the documentation should be supplied by the Contractor who is also responsible for material supplies, it can be arranged in the event of partial performance what parts of the documentation and at what time shall be passed to the Customer. Particular types of documentation can have partial time-limits for their performance, e.g. time for individual construction objects and/or OS.

It is also appropriate to agree the place of performance for particular construction design projects and what negotiations shall be carried out between the Contracting Parties in advance.

The time of the "submission of the construction site" by the Customer to the Contractor should also be agreed (i.e. the handover of the building site in the stage that allows for the performance of the construction works), that may be - especially in case of larger buildings implemented gradually in the agreed partial periods.

It is also necessary to agree for the submission of "building of preparedness", which means an already advanced stage of construction work that will allow for the beginning and continuous performance of supplies erection work by the supplier of the technological part of the construction. Also the so-called "mounting preparedness" can be agreed upon which means a very advanced stage of assembly works falling at one with the technological part of the construction that allows for the construction works of subcontractors necessary for the full completion of the construction (e.g., floor screeds, tiles, paint and other finishing works).

The provisions of Section 2591 CivC specify that if it is necessary to perform the work under the participation of the Customer, the Contractor shall provide him with a reasonable amount of time for its rendering. If the time limit expires, the Contractor shall have the right - 
according to its choice - either to ensure an alternative performance on the Customer's account or, if notified in advance, withdraw from the contract.

This provision shall apply in particular (but not only) on materials that the Customer committed himself to supply to the Contractor (but may be also related to some documentation, etc.).

If the things the procuration of which the Customer committed himself to arrange shall not be provided in time, legal rules specify that the Contractor may provide for it a reasonable period of time and after its expiration he may, after prior notice given to the Customer, provide the things on behalf of the Customer. The Customer is then obliged to pay their price and expedient costs without undue delay, after being requested to do so by the Contractor. The things necessary for the performance of the work to the provision of which the Customer shall not be obliged, shall be arranged by the Contractor.

The subsequent provisions of Section 2592 and 2593 CivC correspond to the previous regulation by the ComC. They provide that the Contractor shall proceed in the performance of the work independently. The opposite - should he be bound exclusively by the instructions of the Customer - applies only in the case if this has been agreed to corresponds to custom practice.

The Customer is entitled to supervise already the performance of the work. In case of constructions supply of machinery technology this function is performed by the Technical Supervisor. Should he find that the Contractor declines from his obligations he may ask for remedy and a proper performance of the work (e.g. by recording a relevant protocol in the Construction or Assembly Journal). If the Contractor is in breach of his obligations and shall not provide for remedy within a reasonable time and the Contractor's performance lead without any doubt to a substantial breach of the contract, the Customer may withdraw from the contract.

The following provision of Section $2594 \mathrm{CivC}$ has essentially the same solution as used previously by the ComC. The obligation to give notice without any delay is given hereby for the case that the nature of things or orders given by the Contractor is inappropriate. This applies when due care is exerted. It does not mean that the Contractor would have to e.g. execute again all the attest certifying the properties, however, he cannot accept the "inputs" from the Customer without giving them the necessary attention.

Should an inappropriate thing or instruction constitute an obstacle to the proper implementation of the work, the Contractor shall suspend the performance of the work until the replacement of work changes the instruction. The deadline for the completion of the work shall be extended by the period of the suspension and the Contractor is entitled to reimbursement of the costs associated with it for the specified period of time. Should the Customer insist on the thing delivered or instruction given the Customer may request that the Customer will confirm the latter in writing. Should the Contractor proceed in accordance with this rule given by Section 2594 the Customer shall not be entitled to compensation of damage resulting from improper things or orders.

In accordance with Section 2595 there is moreover the right of the Contractor to withdraw from the contract should the Customer insist on the performance of the work under the apparently inappropriate instruction or with the use of apparently inappropriate things after a warning is given by the Contractor.

Should the contractor supply a thing processed during the performance of the work, he is as regards the thing - in the position of the seller when the thing becomes part of the work. It is considered that the purchase price is included in the price.

The things that should be supplied by the Customer to the performance of the work shall be 
handed over to the Contractor in the time specified by the contract, otherwise, without undue delay after the conclusion of the contract. In doubts, it shall be considered that the price for the work shall not be reduced by the purchase price of the thing.

Should the Customer not provide the things which he has committed himself to supply, in time, it is stipulated that the Contractor may provide him with a reasonable extra period of time and after its expiry is entitled, after the prior notice, to provide for the things on behalf of the Customer. Should the Contractor so request, the Customer is then obliged to pay for the price and connected costs without undue delay. The things required for the performance of the work that the Customer is not obliged to supply in accordance with the contract, shall be provided for by the Contractor.

This means that the Contracting Parties may agree who shall provide for the things required for the performance of the work. Should the Contracting Parties do so, the contractual arrangements shall apply. If the contract does not provide for these matters, then it is deemed to be agreed that the things shall be provided for by the Contractor.

Should the subject -matter of the work be a thing specified individually, the right of ownership shall be acquired by the Customer. This does not apply when the Contractor has processed a thing supplied by the Customer in another location than the Customer's or on his land or provided for by him, or when the value of the work is the same or higher than the value of the thing processed. In such a case the right of ownership shall be acquired by the Contractor. This is ruled explicitly by Section 2599/1 CivC, the manufacture of things specified by kind determines the ownership of the Contractor's (Section 2599/2 CivC). This corresponds to the previous rules of the ComC.

The following provisions apply for the situation of thwarting of the work. Should the Contractor acquire the ownership right by the processing of the thing and the work will be thwarted for reasons not accountable to the Contractor, the Customer shall not be entitled to the compensation for things he handed over to the Contractor for processing. (The rights from unjustified enrichment according to the CivC shall remain unaffected.) However, should the same situation occur for reasons accountable to the Contractor, the Customer shall provide compensation for its processed thing, or shall return to him a thing of the same kind.

The determination of person who bears the risk of damage to the thing and who has the right of ownership, is of course, of considerable importance. It can be documented, for example, on cases of works in construction. Should the contract specify that the Contractor is the owner (then we can recommend to the Contractor to insure the thing and include the premium in negotiation of the price for fork) and the Customer, for example, fulfilled the conditions for initiation of bankruptcy proceedings, the work will not be included into the assets of the bankrupt. As a consequence of this situation, however, is the fact that the Contractor shall bear the risk of damage to the manufactured thing (unless agreed otherwise).

On the contrary, should the Customer be the owner of the work then the work will be included in the assets of the bankrupt and the debt to pay for the price of the work should be included in the list of claims of all creditors. This debt, according to the situation, may eventually be satisfied only to a minor extent, if at all. However, the Contractor shall not bear the risk of damage to things. Nothing prevents the closing of a potential agreement by the fact that the Customer shall bear a risk of accidental damages, however, as the owner until full payment of the work shall remain the Contractor.

It is therefore possible that the owner will be one Contracting Party and the risk of accidental damages shall be borne by the other Party. It can also be arranged for ownership and risk of damages in case of real properties, existing buildings and the construction site to be passed to the use of the Contractor (for the time of the construction) and different arrangements for the performed work itself. 
The individual contractual arrangements must be based on the specific conditions relating to the Contracting Parties and the nature of the work. In particular, it is necessary to take into account the way and terms of payment, if any Contracting Party has taken a credit, whether the work is subject to a lien, whether it shall become part of another work, etc.

We should not omit the arrangements for early securing against damage and insurance of the work at the time of construction in process. The contract should also address the issues associated with potential termination of the obligation to perform the work.

When dealing with questions of ownership right, we may encounter in practice the situation that incompatible solutions are chosen as for relations between the Customer and the Contractor on the one hand, and the relations between the Contractor and its Subcontractor on the other hand. For the identical subject-matter, if one contract is agreed (as follows from the law), in the case of the ownership of the Customer and a subcontract to the latter the subcontractor's right of ownership is agreed. Such a solution should be avoided and the entire supply system should have an identical ownership regime.

According to Section 2604 CivC the work is performed when it is completed and passed to the Customer. Both conditions must be met. The work is held to be completed if its capacity to serve its purpose is demonstrated. The Customer takes over the work performed with the reservations or without reservations. The Customer should properly perform the inspection of work. Should the work be taken over without reservations the court will afterwards not adjudge him the right to reclaim apparent defects of the work should the Contractor object that the right has not been exercised in time.

As the eligibility of the work to serve its purpose indicates the completion of the work, it is suitable to state the purpose of the work directly in the contract. The Customer should become acquainted with the work properly. He shall in particular exercise the right to claim with reservation (s) apparent defects of the work.

By agreement it shall be determined when the performance of the work will be completed, including the agreed conditions of the tests and the conditions for recording the Protocol on Takeover (including its content). A completion of the work in parts can be agreed as well, by separate construction objects and operational settings. At the same time, corresponding bonuses and penalties (fines) in relation to these periods can be arranged for.

The completion of the work consisting in construction activities will be more complicated. The timely fulfillment and proper performance will often depend on the interaction (agreed upon in an appropriate way) of other persons, in particular of the Customer (passing of the construction site as mentioned above or handover of construction documentation).

In many cases, the Contractor is unable to secure the complete performance of the work through its own employees, but will arrange for subcontracts (in particular, wiring, insulation, air-conditioning, etc.). The CivC allows such solution. The Contractor may namely assign the performance of the works to another person should the contract or the nature of the works not imply the contrary. When the work is performed by another person, the Contractor is responsible as if he would perform the work by himself.

The contractor can also conclude with its subcontractors contracts for work but also sale contracts and other types of contracts, including innominate contracts. For these cases we can recommend that the Contractor negotiate the terms and conditions of subcontracting in conformity with the terms of the (main) contract with the Customer.

\section{CONCLUSIONS}

We can say that the treatment under consideration is in line with the legislation in other developed countries. In the case of a contract, reference may also be made to the use of the 
FIDIC business terms. We can appreciate very positively the regulation by Section 2628 CivC. It specifies that the Customer does not have the right to refuse takeover of a construction because of isolated minor defects that as such and even in connection with others does not prevent the use of the construction neither functionally or aesthetically and that do not limit its use in a substantial way. The ratio of this provision is that in case of constructions we can never avoid minor defects (e.g. paint). Also the regulation of other states (e.g. conditions for the performance of construction in German law) contain the same rules. In fact this reality was already mentioned in the Economic Code which was broader and covered also minor individual defaults. The ComC did not contain such a rule if not agreed by the Contract Parties; therefore it has appeared to be too strict. However, we must stress in this context the agreement must cover only defects defined by Section 2628CivC.

As regards the rights emerging from defective performance, the CivC of 1964 defines the period during which they may be claimed as a period of three years (Section 646/3), but the ComC as a period of five years (Section 562/2). The new regulation of CivC takes over the rule of ComC. Implementing the regulation to CivC may, however, in justified cases provide for a shorter period for some parts of the construction of up to two years. However, there is also a rule that specifies: "Should the parties agree a shortening of this period, it shall not be taken into consideration, if the Customer represents the weaker Party to the contract."

Section 2360 CivC provides for cases when there are other persons committed jointly and severally with the Contractor and when the contractor shall relieve itself of the obligation for defects of the construction. This provision rules for joint and several liability of specified persons together with the Contractor. Section 2360 CivC provides for cases when there are other persons committed jointly and severally with the Contractor and when the contractor shall relieve itself of the obligation for defects of the construction. This provision rules for joint and several liability of specified persons together with the Contractor. These are

- Partial supplies of the contractor

- Person who supplied the building documentation,

- Person who carried out the construction supervision.

The subcontractor, however, is not liable if he proves that the defect was caused only by the decision of the Contractor or of the person carrying out the construction supervision. The person who supplied the building documentation is not accountable if he proves that the defect did not cause an error in the construction documentation.

The Contractor shall not be accountable for defects of the construction if he can prove that

- that defect was caused by an error in construction documentation, supplied by a person chosen by the Customer,

- the only failure was in the construction supervision, the person of Supervisor chosen by the Customer.

Other provisions adopt with minor changes the previous legislation in Section 556 to 559 ComC. New rules amended are related to the works in competition that - although very necessary - were missed in our legal system so far.

Should the work consist in another result than the manufacture of things or maintenance, repair or modification of things, the Contractor shall proceed in performing work as agreed and with professional care so as to achieve the result specified by the contract. It is therefore specified that the work may result in other activities, for example. Software, project documentation or other documentation.

The result of the activity, i.e. work with intangible results, shall be passed to the Customer. It is deemed to be passed if 
- completed and

- the Contractor allows the Customer its use.

The result of the activity that is subject to rights of industrial or other intellectual property can be provided by the Contractor also to persons other than the Customer, if this was agreed. Should the contract contain no explicit prohibition on such a provision, the Contractor shall be entitled to do so unless it is contrary to the interests of the Customer due to the nature of the work. Crucial for the provision of the result to other persons is the arrangement of the Contracting Parties. Here a suitable agreement of the Parties is strongly recommended.

Should the subject-matter of the work consist in the result of activities protected by the industrial property law or other intellectual property rules, it shall be deemed that the customer has provided the work to the Contractor for the purpose arising from the contract.

As we can see a refutable presumption is put to the rule that the result of the activity specified by the contract has been provided by the Contractor to the Customer for the purpose arising from the contract. Also in these cases, it is appropriate to agree on suitable arrangements between the parties.

The last provision on the contract for work in the ComC specifies that the provisions of the part dealing about work with intangible outcomes shall apply mutatis mutandis to the outcome reached in accordance with the provisions of the public promise (competitive work).

The importance of contractual negotiations for contracts for work is evident exactly for the wide range of contractual freedom allowed by the $\mathrm{CivC}$ and from the fact that the Code does not contain rules on partial issues and leaves them to the Contracting Parties (e.g., supply of spare parts, service, length of the warranty period, sanctions, invoicing, payment, tests, takeover, cooperation on the construction site, details of taking records in the Construction Journal, etc.). The recommendations contained in the present paper that are based on practical experience of the author may be used for the contractual negotiation.

\section{KEY WORDS}

Civil law, Business law, Civil Code, New Civil Code, Commercial Code, Contract for Work

\section{KLÍČOVÁ SLOVA}

Občanské právo, Obchodní právo, Občanský zákoník, Nový občanský zákoník, Obchodní zákoník, Smlouva o dílo

\section{REFERENCES}

1. BEJČEK, J., MAREK, K., KOTÁSEK, J., ONDREJOVÁ, D. Nástin obchodního práva. II. 2nd Edition. Brno: Masarykova univerzita, 2012. 111 p. Edice multimediálních učebních textů č. 78. ISBN 978-80-210-4978-9.

2. ELIÁŠ, K.; ZUKLÍNOVÁ, M. Principy a východiska nového kodexu soukromého práva, Linde Praha, a. s., Praha 2001.

3. MAREK, K. K uzavírání smluv. Právní fórum, Praha: Wolters Kluwer C̆R, 2012, vol.. 2012, No. 4, p. 138-143. ISSN 1214-7966.

4. MAREK, K. OZ v praxi, smlouva o dílo, Bulletin advokacie, Praha: Česká advokátní komora, on line, 2018, p.1-15, ISSN 10805-8280.

5. MAREK, K. Contract for Work Under Civil Code. In Procedia Ekonomics an Finance 2014, ISI Knowledge -WoS, p.387-396,J ournal publishong 24 jul 2014 Procedia 
Ekonomics and Finance, nakladatelství Elsevier, Oxford, United kindom, 2014, N12 ze 24.7.2014, ISSN 2212-5671. Dostupné na https://doi.org/10.1016/S2212-5671(14)00359-

6. MAREK, K., HAJNIŠOVÁ, E. Contract for Work, International scientific and practikal conference of young scientists and students 14.- 15. 5. 2015, Sbornik z konference Time of challenges and opportunities : problems, solution and prospects, Riga: Baltská universita, 2015, p. 373-378, ISBN 978-9984-47-102-0.

\section{KONTAKTNÉ ÚDAJE AUTORA}

prof. JUDr. Karel Marek, CSc.

Head of the Department of Civil and Labor Law

University of Finance and Administration, Estonská 500

10100 Prague 10, Czech Republic

e-mail address: k.marek@centrum.cz 